\title{
In Memory of a Deadly Voice: Ruby Hunter, 1955-2010
}

John Harding and Oliver Haag

Ruby Hunter was more than a song writer: her songs are autobiographical, socio-critical and eminently historical, revolving around political issues, such as the Stolen Generations, Indigenous sovereignty and women's issues. Her music, partly performed in collaboration with her life partner Archie Roach, is not merely entertainment and pleasure. Hunter's songs are deeply personal. They reveal her own experiences of having been forcibly removed from her family and the path of becoming a devoted artist, activist and intellectual. Ruby' Story tells of her own life as a member of the Stolen Generation-without bitterness or reproach. Let My Children Be is a powerful voice for diversity and plurality in Australian society.

Ruby Hunter was born in South Australia in 1955 and died of a heart attack in February 2010. Despite her relatively short life, she became a songwriter of international recognition.

Zeitschrift für Australienstudien honours Ruby Hunter's life and work. It presents a poem by John Harding which captures Hunter's road to becoming an artist and includes a selected discography of her songs.

\section{I raise my glass to Ruby}

\author{
by John Harding
}

I remember the 80 's in suburban Fitzroy, my youth at that time meant my memory is clear.

You could see the camaraderie that exuded silently from all the Kooris, a smile a kiss and a handshake our passports to each other. 
You could honestly smell the love and respect we had for one another.

I remember a quieter Ruby then, oh she still had the twinkling vibrant eyes and the big laugh, the smile that lit up a footpath or a park, but quieter then.

See she hadn't picked up her guitar onstage yet,

Then I saw here emerge out from behind her hubby Archie Roach, Her voice like the spine of Archie's C note, chillingly haunting and hauntingly chilling,

her voice was pure unadulterated slap you in the face pride. The collective pride of all her peoples exhaled with every breath of that blak velvet tone.

Ruby riddled us all with bullets of truth and pain and humour that passed thru our hearts, they slowly melted while she told us ten minute stories about five minute songs,

Archie gently urging her to start playing her guitar without looking at her to avoid a steely glare. What love and respect they had...

Ruby asking my mother Eleanor to be in their video clip they shot in their backyard in Reservoir, and calling her aunty, always calling her aunty.

If cheekiness, humour, beauty, talent loyalty and love could be wrapped up in a suburb it was Fitzroy, if the suburb could be wrapped up in a woman,

It was Ruby.

(For Archie Roach and Ruby Hunter)

\section{Discography}

1990: Charcoal Lane (with Archie Roach; titles: Native Born;

Charcoal Lane; Munjana; I've Lied; Down City Streets; Took the Children Away; Sister Brother; Beautiful Child; No No No; Summer Life) 
1993: Jamu Dreaming (with Archie Roach; titles: Weeping in the Forest; From Paradise; Mr T; Love in the Morning; Tell Me Why; Walking into Doors; Wild Blue Gums; So Young; Angela; Jamu Dreaming; There Is a Garden)

1994: Thoughts Within (titles: Kurongk Boy, Kurongk Girl; So Close, So Near; Let My Children Be; Whos to Blame; Proud, Proud Woman; A Change is Gonna Come; Aunty Sissy; Woman's Business; Kutjeri Lady; Wet Heart, No Tears; I've Been Waiting; Modern Day Girl)

2000: Feeling Good (titles: I Am A Woman; It's Okay; In the Right Way; Ain't No Time; Ngarrindjeri Woman; Aurukun Moonlight; Take It Easy; Something Special; Wise Ways; True Lovers; Why Won't You Believe Me; Welcome to All People)

2005: Ruby (Ruby's Story) (with Archie Roach; titles: A Child Was Born Tonight; Ngarrindjeri Woman; Nopun Kurongk; Held Up to the Moon; Was My Soul in the River's Flow; Daisy Chains, String Games and Knuckle Bones; Took the Children Away; Coolamen Baby; Little by Little, Down City Streets; Old So \& So; Kura Tungar) 